\title{
THE VOLUNTARY ADJUSTMENT OF RAILROAD OBLIGATIONS
}

\author{
Hubert L. Wnx*
}

The enactment during the first session of the 76 th Congress of Chapter XV of the Bankruptcy Act ${ }^{1}$ providing for "Railroad Adjustments" has attracted new and widespread attention to what in the past decade has been a relatively unimportant aspect of railroad financial tactics, the so-called "voluntary" adjustment or reorganization.

In the one hundred odd years in which the railroads have been a significant part of the American scene, over half of them have at one time or another undergone a capital overhauling. ${ }^{2}$ Before the passage of Section 77 of the Bankruptcy Act ${ }^{3}$ the typical railroad reorganization was accomplished through an equity receivership which customarily terminated in foreclosure proceedings and the transfer of the road's assets to a new corporation. Not infrequently, however, the receivership ended with most of the creditors and security holders of the old corporation accepting a plan of reorganization, thus obviating the necessity for foreclosure and the creation of a new corporation.

This represented one type of voluntary reorganization though often it differed from a so-called "involuntary" one only in the omission of foreclosure, one of many pressure devices used to obtain acceptance of a plan. Since either proceeding functioned typically through committees which usually held blanket authorizations to bind the owners of deposited securities to any plan approved by the committe, there was little that was truly voluntary about such a reorganization even in the absence of foreclosure. To the average security holder the method of terminating the receivership mattered little, for having deposited his securities with a committe he was foreclosed from any further voluntary action in the proceedings. Of course, even when foreclosure was omitted, the threat thereof served frequently as a more than adequate substitute.

- A.B., 1935, JD. 1937, Universiry of Chicago. Member of the Wisconsin Bar. Atrorney, U. S. Departpent of Justice. Formerly Attorney, Securities and Exchange Commission, 193S-1939, U. S. Treasury Deparment, 1939-1940, engaged, in both positions, in activities relating to railroad reorganization and adjustment. Author: Chapter XV of the Bankruptey Act-An American Adaptation of the Fait Accompli (I940) 7 U. OF CHI. L. REv. 203.

${ }^{2}$ Act of July 28, 1939, Public No. 242, 76th Cong., ist Sess, 15 U. S. C. A. \$1200 ef seg.

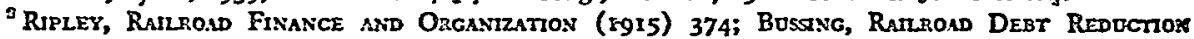
(1937) 8.

47 STAT. 1474 (1933), as amended, II U. S. C. A. \$205 (r939). 
The other type of voluntary adjustment was accomplished without resort to the courts. The management prepared a plan and sought to induce all affected creditors and security holders to accept its proposal. Often such plans were effected without the formation of any committees. Frequently, too, these originally voluntary proceedings became involuntary through conversion into what was known as a "short receivership.""

The principal weakness of both types of voluntary proceedings from the point of view of the management was that unless substantially all affected security holders and creditors had either deposited with friendly committees or could be induced separately to accept the plan, a real problem of handling dissenters was presented. Among the advantages were the avoidance of foreclosure and the problems attendant thereon and the preservation of the old corporation."

With the shift in attitude toward corporate reorganization and financing evidenced in part by the enactment of such statutes as Sections $77,77^{B}$ and Chapter $X$ of the Bankruptcy Act, ${ }^{\circ}$ as well as the Securities and Securities Exchange Acts, ${ }^{7}$ equity receiverships fell into decline and the first type of voluntary reorganization became extinct. The attempts at negotiations between the management representing the stockholders and the creditors without resort to any court proceedings continued, however, hindered always by the problem of handling dissenters.

Among the railroads such voluntary adjustments were limited almost exclusively to effecting the extension of single issue maturities and did not involve any largescale capital adjustments. ${ }^{8}$ Even these single issue extensions were carried through only with great difficulty because of the absence of any effective method of dealing with dissenters short of purchasing their securities.

It was somewhat surprising, therefore, when, in the fall of 1938 , voluntary plans affecting most of the outstanding indebtedness of each road were presented for both

"The "short receivership," strenuously criticized in the S. E. C.'s Protective Committe Study, was surprisingly similar to the procedure authorized by Chapter XV. See S. E. C., REporrs ON THE STUDY AND Irvestigation of the Work, Activitjes, Personnex, and Functions of Protective and Reorganization Counsirtees, Pt. I, p. 312 et seq. See also the Commission's letter to Senator Burton K. Wheeler, Hearings of the Senate Committe on Interstate Commerce on H. R. 5407, 76th Cong., ist Sess. (1939) 62 (hereinafter cited as "Senate Hearings").

${ }^{8}$ Preservation of the existing corporation may be desirable for several reasons. The cost of organizing a new corporation may be considerable, e.g., it was estimated that it would cost the Rock Island \$800,000 to organize a new corporation and qualify it to do business in Illinois and lowa. See Hearings of the Special Subcommittee on Bankraptcy and Reorganization of the House Committee on the Judiciory, on S. 1869, 76th Cong., Ist Sess. (1939) Pt. 1 , p. 458. The legislative charters granted many roads, esg., the B. \& O., contain desirable provisions which make retention of the charter advantageous,

\$77, 25 amended, II U. S. C. A. \$205 (1939); \$77B, as amended, II U. S. C. A. \$207 (1937); Chapter X, II U. S. C. A. \$\$501-676 (1939).

${ }^{5}$ Securities Act of 1933,48 STAT. 74, 15 U. S. C. A. 5577 b-bbbb (Supp. 1939); Securities Exehange Act of 1934, 48 STAT. 895 (1934), 15 U. S. C. A. 55782-jj (Supp. 1939).

One of the few large-scale plans attempted was that for the St. Louis \& San Francisco Railroad which was presented originally as a straight voluntary plan to be effected without court proceedings. The road subsequently went into equity receivership in the hope of carrying out the plan through 2 "short receivership." This was abandoned in 1933 and a petition filed under $\$ 77$ of the Bankruptcy Act. See S. E. C., REFORT, supra note 4 , at $318 \mathrm{at}$ seg. 
the Lehigh Valley ${ }^{9}$ and the Baltimore and Ohio Railroad Companies, ${ }^{10}$ and projected plans for several other roads were rumored to be under consideration. Both the plans referred to contained provisions substantially similar to those in the B. \& O. plan providing that assents thereto were to be binding in proceedings under Section 77 of the Bankruptcy Act "or other law at the time in force, or through such other legal proceedings as the Board of Directors may deem appropriate to effectuate the Plan as to non-assenting minorities."11

The ambiguity contained in the reference to "other law" was cleared up early in the first session of the 7 th Congress with the introduction in the House of Representatives of H. R. 3704, proposing the addition to the Bankruptcy Act of Chapter $\mathrm{XV}$ to provide for "Railroad Adjustments."

While the proposed procedure contemplated no committees, so that it would still be necessary to obtain individual acceptance of the plan by crediturs and security holders, the more important problem of dissenters was solved by empowering the bankruptcy court, upon the acceptance of the plan by a specified minimum of security holders and creditors, to bind all parties including dissenters thereto. On July 28, 1939, after considerable amendment and with a time limitation of one year imposed, Chapter XV became law.

Pursuant to this time limitation, the present Chapter XV expires July 31, 1940. Since latest indications are that it will not be extended, no attempt will be here made to analyze its specific provisions. On the other hand there will be few, if any, largeseale voluntary plans effected in the future unless some similar method of binding dissenters is provided. An examination of the Chapter XV procedure and plans will be useful, therefore, in determining both whether new legislation is desirable and, if so, what form it should take.

\section{The Procedure}

Virtually all recent corporate reorganization legislation ${ }^{13}$ as well as the new railroad reorganization bill now before Congress ${ }^{14}$ has been designed to afford all interested parties, the court and the appropriate governmental agencies a full opportunity to examine the corporation involved and all proposals for its reorganization: Chapter XV, however, presents a procedure quite the reverse. Not only is there but: one plan, that proposed by the management, but the procedure is so geared that

- Dated Aug. 25, 1938, 230 1. C. C. 685 (1938).

${ }^{10}$ Dated Aug. 5, 1938, 230 I. C. C. 243 (1938), 29 F. Supp. 608 (D. Md. 1939), cert. denied, 60 Sup. Ct. 470 (1940). The material sent to security holders is also reproduced in Senate Hearings, II7 et seq.

21 Id. $2 t 128$.

${ }^{25}$ H. R. 3704 was subscquently reintroduced in amended form as H. R. 5407 which, as further amended, finally becrae law.

${ }^{28} 577$; S77B; Chapter $X$. With respect to the safeguards provided by Chapter $X$ and their absence in Chapter XV, the following language of the Supreme Court, while relating to Chapter XI, is equally applieable to Chapter XV: "No comparable safeguards are found in Chapter XI. Every phase of the procedure bearing on the administration of the estate and the development of the arrangement is under the control of the debtor. The process of formulating an arrangemeat and the sclicitaion of consent of creditors, sacrifices to speed and economy cvery safeguard, in the interest of thoroughness and disinterestedness, provided in Chapter X." S. E. C. v. U. S. Realty Improvement Co, 60 Sup. Ct ro44 (1940).

24 H. R. 9447, 76th Congon 3d Sess. (1939). 
neither the I. C. C. nor the bankruptcy court, the only disinterested agencies possessing jurisdiction, can effectively examine this plan and perform the protective functions delegated to it. Most of the safeguards necessary to insure an economically sound as well as a fair plan are sacrificed to permit a speedy proceeding.

The initial step in the procedure is for the management of a railroad faced. with principal or interest maturities which it cannot meet to formulate a so-called "plan of adjustment." ${ }^{\text {"S }}$ The next step is to obtain acceptance of this management distress plan by as many of the affected creditors and security holders as possible. To this end a vigorous solicitation is begun in which the plan is presented as persuasively as the proxy regulations of the Securities and Exchange Commission will permit."

When holders of at least $25 \%$ of the affected claims have assented to the plan, ${ }^{17}$ it may be submitted to the I. C. C. for consideration under Section $20 a$ of the Interstate Commerce Act. ${ }^{18}$ The Commission is required to make certain specific findings, such as that the railroad is not in need of reorganization, that its inability to meet its maturities is reasonably expected to be temporary only, and that the plan meets certain standards, e.g., is in the public interest, is feasible, financially advisable and not likely to be followed by need of reorganization, does not provide for fixed charges in excess of probable earnings, enables necessary future financing, allows for adequate maintenance of the property, and is consistent with the proper performance by the railroad of its functions as a common carrier. ${ }^{19}$ It is to be noted that the Commission is not specifically required to find that the plan is "fair and equitable." This means that although Chairman Eastman expressly requested that the legislation clarify the Commission's duties with respect to determining the fairness of plans presented under Section 20a, the uncertainty continues. ${ }^{20}$ As a result, the Commission has approved plans which seem clearly not to meet the standards of the Boyd ${ }^{21}$ and Los Angeles Lumber Products $C_{0 .}{ }^{22}$ cases, even though this fact was pointed out by dissenting Commissioners. ${ }^{23}$

In the same letter in which he requested clarification of the Commission's duties as regards the fairness of proposals presented for approval under Section 20a, Chairman Eastman also pointed out that Commission consideration of such a plan is inevitably affected by the fact that much time and money have already been spent on the plan at the time of its submission to the Commission and that it has been accepted by a substantial number of the interested parties."

${ }^{25}$ 5710(1). Chapter XV excludes from its provisions roads which are or have been within the past ten years in equity receivership or 577 proceedings.

1e See S. E. C. Regulation X-14, as amended, Feb. 15, 1940, promulgated under Securities Exchange Act, $\mathrm{Sr}_{4}(\mathrm{a}), 15$ U. S. C. A. $\$ 78 \mathrm{n}(2)$ (Supp. 1939).

4 I StAT. 494 (1920), 49 U. S. C. 5202.

${ }^{27} 5710(1)$.

${ }^{20}$ See letter of Chairman Eastman to Senator Wheeler, Chairman, Senate Committee on Interstate Commerce, Senate Hearings, 186, i89.

${ }_{22}$ Northern Pac. R. R. v. Boyd, 228 U. S. 482 (1913).

22 Case v. Los Angeles Lumber Products Co., 308 U. S. 106 (1939).

22 Commissioners Mahaffe and Eastman, Montana, W. \& S. R. R. Financial Adjustment, Fin. Doc. No. 12517 (1939).

2' Ses Senate Hearings, 186 et seg. The statute recognizes the importanes of this infuence and with remarkable naiveté admonishes both Commission and court to scrutinize the facts and make their findings 
Rather than relieving this element of pressure, Chapter XV enhances it, for acceptance of the plan by a minimum of $25 \%$ of the affected parties is made a prerequisite to Commission consideration. ${ }^{25}$ As a matter of fact, the managements have frequently presented the plan to the Commission, only after an even larger percentage of assents has been received. ${ }^{26}$

The position of the Commission under Chapter XV is further impaired by limiting its action to either approving or disapproving the plan as submitted with no apparent authority to modify any of its provisions. ${ }^{27}$ Added to this is the important factual element that unless the Commission approves the plan the railroad involved will undoubtedly be thrown into reorganization or receivership proceedings. While a thorough-going reorganization may be precisely what the road needs, the I. C. C. will be most unwilling to assume the responsibility for the initiation of such proceedings. This unwillingness has been displayed by the Commission on many occasions, among them the opinion on the B. \& O. plan. ${ }^{28}$ After poirting out important weaknesses in that plan, the Commission concluded that nevertheless it would give its approval, stating that the only alternative open to the road, if approval were withheld, was reorganization.

Before the Commission had acted on any plans under Chapter XV, the writer suggested that, in view of the elements just discussed, it was most unlikely that any Chapter XV plan would be rejected by the I. C. C. ${ }^{29}$ The Commission has no real choice. It starts with an ambiguous statute, a plan on which much time and money have been spent and which has been accepted by a substantial number of the interested parties. It possesses a natural desire to avoid responsibility for precipitating the financial reorganization of a private corporation and can do so only by approving the plan as submitted, since it appears to have no authority to require any modifica-

\footnotetext{
"independently of the extent of acceptances of such plan and of any lack of opposition thereto." \$5710, 725(3). The court in addition is instructed to ignore the fact that the Commission has approved the plan and has macie findings similar to those to be made by the court. 5725(3). A reading of any of the Commission's decisions on Chapter XV plans, infra note 42 , or the decision of the special court in the B. \& $O$. case, supra note 10 , will demonstrate the futility of any such provision.

${ }^{25}$ In this connection, $f$. 577 (d), providing for Commission and court consideration of any 577 plan hefore submission to creditors; Chapter X, $\$ 176$, prohibiting solicitation of assents to a Chapter X plan until after its approval by the court.

"The plan of the Montana, Wyoming \& Southern R. R. had been accepted by holders of more than three fourths of the bonds affected, I. C. C. Fin. Doc. No. 12517 (1939), that of the Chicago, Memphis \& Gulf R. R., by holders of more than $43 \%$ of the affected bonds, I. C. C. Fin. Doc. 12663 (1940), and that of the Peoria \& Eastern Ry, by holders of over $36 \%$ of the affected bonds, I. C. C. Fin. Doc. No. 12753 (1940).

${ }^{3}$ See $\$ 710$ which refers merely to the issuance of an order authorizing the securities called for by the plan. The 1. C. C. did, howcrer, condition approval of the Chicago, M. \& G. R. R. plan upon the inclusion of an additional agreement by the Illinois Central, the owner of all the road's stock, not to terminate its lease with the Chicago, M. \& G. before the extended maturity of the bonds affected by the plan. Sce I. C. C. Fin. Doc. No. 12663 (1940).

24230 I. C. C. 243 (1938). Another striking example is the case of the Chicago, M. \& G. R. R. plan, supra note 26 , which the Commission approved despite an adverse recommendation by the examiner and the dissent of Commissioners Eastman, Patterson, Mahaffe and Miller, the latter two constituting = majority of the Finance Division which handled all Chapter XV plans.

s" See Will, Chapter XV of the Bankruptcy ACt-An American Adaptation of the Fait Accompli (1940) 7 U. OF CHI. L. REv. 203, 209.
} 
tion thereof. Moreover, public servants are not impervious to outside pressure and that provided by Chapter XV is great. As a result, all Chapter XV plans have been approved by the Commission.

After receiving Commission approval the plan is next presented for final approval to a special three-judge district court to be convened in the manner provided by Section 266, as amended, of the Judicial Code.30 The plan may not be filed with this court until it has been accepted by creditors holding more than two thirds of the aggregate amount of affected claims including a majority of each affected class ${ }^{32}$ and may not be approved until accepted by holders of at least three fourths of all affected claims, and three fourths of each class. 32 Lacking any technical staff, the sourt faces an even more dificult task than the I. C. C. The plan has the approval of a very large percentage of the interested parties and has been approved by the Commission. Finally, the amount of time and money expended on the plan is considerably greater than at the earlier I. C. C. proceedings. All these factors combined result in a pressure for approval which is virtually irresistible and represent a return to one of the phases of equity receiverships which modern reorganization legislation has been specifically designed to correct. ${ }^{33}$ It is under these circumstances that the ultimate goal of the proceedings is reached, the order of the court approving the plan and binding all dissenters to it.

While the discussion thus far has indicated that neither the 1. C. C. nor the appropriate court is likely materially to amend or reject any of these management plans, nothing has been said about the possibility of security holders acting in their own behalf and either rejecting the plan or actively opposing it before the Commission or the court.

In this connection it may be pointed out that as a general propesition security holders have neither the information nor the resources necessary to undertake effective individual action. In addition, as more fully discussed later, Chapter XV plans are basically deferment plans having as their chicf attraction the fact that no final reduction in maturities is effected. Such plans appeal to the optimism of investors and are not likely to aiouse strong opposition. Finally, certain provisions of the statute effectively discourage any organized opposition to the plan. The absence of any provisions relating to independent committees plus the fact that fees are limited to "amounts or consideration, directly or indirectly paid or to be paid by or for the petitioner for expenses, etc." ${ }^{34}$ militates strongly against the formation of such committees. While protective committees have often left much to be desired, ${ }^{\text {s5 }}$ the solution of that problem lies not in their abolition but in better regulation of their

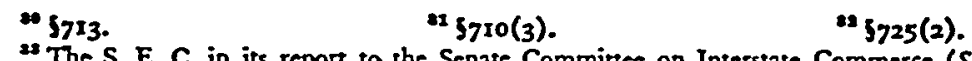

${ }^{23}$ The S. E. C. in its report to the Senate Committce on Interstate Commerce (Senate Hearings, 61) concluded: "In substance, the effect of the bill appears to be to limit the court to approving and confirming so-alled "voluntary' or management plans" and continued by pointing out the similarities between the Chapter XV procedure and the old "short receiverships." See S. E. C. REponrs, supra note 4, at 312 et seg. " $5725(6)$ (italics added).

${ }^{2}$ See S. E. C. Repoxts, supta note 4, esp. Pts. I and II. 
activities. ${ }^{\text {so }}$ Granting the management an outright monopoly to represent securityholders in reorganization proceedings is antithetical to all the recent attempts made to assure the freedom of committees from management domination and is a real step backward.

The streamlined, high-pressure character of the procedure is also apparent from other provisions of the statute. For example, while the court has jurisdiction to enjoin any proceedings which might be inconsistent with or might interfere with the effective execution of the plan, it is expressly prohibited from appointing a trustee or receiver or otherwise controlling the operation or administration of the carrier involved." Further, the court is to be convened "immediately" following the filing of the petition, ${ }^{38}$ is "promptly" to enter its order approving or disapproving the petition as filed," and is to hold the hearings on the plan "promptly."10

The danger of falling into serious technical or legal errors in such a proceeding is illustrated by a recent development in the $B$. \& $O$. case. The trustee under the indenture securing the B. \& O.'s Five-Year Secured Notes, the only issue on which interest was permanently reduced under the plan, recently filed a petition for instructions with respect to substantial dividends received and to be received by it on the large blocks of Reading Company stock pledged to secure the Notes. ${ }^{11}$ A problem arises because the original indenture which was not modified in this respect provides that the trustee shall pay dividends received on the collateral to the B. \& O. only when the Notes are not in default or when, among other things, the combined capital and surplus of the Reading Company as shown by its books is $\$ 225,000,000$ or more. The book capital and surplus of the Reading have ranged between \$233,000,000 and $\$ 236,000,000$ over the period in which the $\$ 1,412,000$ in dividends now held by the trustee was received, but included in the assets on which such capital and surplus are based is a block of common stock of the Central Railroad of New Jersey carried at its cost of approximately $\$ 24,000,000$. Since the Jersey Central is in Section 77 proceedings the value of the stock, if any, is greatly reduced. If the court should refuse to construe its earlier order as authorizing the trustee to pay the dividends to the $\mathrm{B}$. \& $\mathrm{O}$, it will probably be necessary to resolicit holders of the Secured Notes for their assent to a modification of the indenture in that respect or the B. \& O. will be unable to obtain these dividends which it sorely needs and the equivalent of which it will be paying noteholders in annual interest. The noteholders, however, may be unwilling to give up their advantage and the whole plan may be jeopardized. It is unlikely that such a gap would have survived the extended negotiations attendant upon the formation of the typical reorganization plan. The in-

20 This is the conclusion reached by the S. E. C. (id. Pt. II, at 528 et seq.) and is reflected in the provisions of Chapter $X, 55209-213$, relating to such committees.

27 515. 285713.

30 3714.

12 In re B. \& O. R. R. (D. Md., File No. 9294), Petition of the Trustee Under the Secured Note Indenture for a Constiuction of Certain Provisions of the Decree Confirming the Plan (Crder No. 16), filed May 29, 2940. 
adequate consideration of the plan permitted by Chapter XV greatly increases the possibility of such unfortunate situations.

\section{The Plans}

The discussion thus far has been directed principally to demonstrating that the procedure authorized by Chapter XV is so geared as to make it highly unlikely that any management plan will be materially affected by either the I. C. C. or the court. Very little has been said about the character of the plans proposed under the procedure, an equally important aspect of the present analysis, for unless they are likely to require amendment, the procedural weaknesses are of little consequence.

As of July 1, 1940, six plans had been filed under Chapter XV with the I. C. C. or with the appropriate federal court. ${ }^{42}$ While they vary because of differences in the capital structures and financial conditions of the individual roads, certain general characteristics may be pointed out. Most of these are common not only to the Chapter XV plans but to any voluntary plan since they result from influences attendant upon any attempt by the management of a corporation to negotiate directly with security holders.

First, none of the six plans alters stock interests. Furthermore, it is unlikely that any voluntary railroad plan will. This is true for several reasons. In the first place, the plan is invariably promulgated by the management as a device for meeting impending interest or principal maturities. ${ }^{43}$ The immediate hurdle therefore, does not involve stock interests, and, since the management represents the stockholders, the..incentive is all against affecting their interests. In addition, because stockholders possess no present claims which may be deferred or compromised, it is virtually impossible to devise a plan affecting them without not only doing so adversely but also without offering any present inducement for the:r acceptance of the adverse treatment. Unless unusually persuasive in terrorem arguments can be presented for their agreement to such a plan it will bc impossible to obtain the substantial acceptance necessary to effertuate any voluntary plan either apart from or under $\mathrm{Cl}_{\text {tapter }} \mathrm{XV}$. In the six plans under consideration not only are stock interests untouched, but the claims of unsecured creditors also are not modified in any way.

Second, since the function of the plan is to avoid receivership or Section 77 proceedings, it must provide some method of meeting the menacing maturities, and, so that the solution may be more than temporary, must also provide for either cancellation, reduction, or deferment of other forthcoming maturities. In the absence of unusual inducements, such as a present cash payment, however, secured creditors

"2 Wichita Falls \& Southern R. R. Financial Readjustment, 221 I. C. C. 585 (1937); Lehigh Valley R. R and Subsidiaries Financial Readjustment, 230 I. C. C. 685 (1938); B. \& O. R. R. Financial Readjustment, 230 I. C. C. 243 (1938); Montana, Wyoming \& Southern R. R. Financial Readjustment, Fin. Doc. No. 12517 (1930); Chicago, Memphis \& Gulf. R. R. Financial Readjustment, Fin. Doc. No. 12663 (1940); Pearia \& Eastern R. R. Financial Readjustment, Fin. Dox. No. 1275j (1940).

"Chapter XV was apparently available only for management plans. Sce 35710,725 (6). Frovisions like the later section make it virtually impossible for anyone but the management to undertake the expense of a voluntary plan. 
are not likely to agree to cancellation or reduction of either interest or principal, particularly when unsecured creditors and stockholders are not asked to make any sacrifice of their inierest in the corporation:

This means, as the six plans demonstrate, that voluntary plans will be basically deferment plans with reduction of either principal or interest being effected only in unusual situations. Only two of the six plans affect more than a single issue and both of these are almost exclusively deferment plans." The B. \& O. plan, to consummate which Chapter XV was enacted, is typical of what may be expected in any voluntary plan affecting more than a single class of securities of a large carrier. It provides for both partiai and complete deferments. Portions of interest on some issues will continue as fixed charges and be paid currently while other portions, the payment of which is made contingent upon earnings, will not be wiped out if unpaid but merely deferred. In fact, the management strongly urged as a reason for acceptance of the plan that it called for no principal reductions and, with one minor exception, no final reduction in interest but merely for a moratorium on the payment of parts thereof: ${ }^{45}$

Two of the plans, involving single issues of somewhat smaller roads, do effect reductions of principal and interest through the inducement of a present cash payment. ${ }^{48}$ This is, of course, a very desirable accomplishment. It is limited in its possibilities, however, to a relatively small number of roads, for it is to be noted that both these carriers had single mortgages and both had or were able to obtain the necessary cash, circumstances almost essential to the successful carrying out of such a plan. Very few Class I railroads have single mortgages and few of those have or could get sufficient cash to present the necessary inducement.

That such plans can probably be effected without a special procedure is demonstrated by the recent experience of the Boston and Maine Railroad in successfully carrying out its plan without resort to Chapter XV.77 While the Boston and Maine plan involved more than $\$ 100,000,000$ of securities, the larger of the two similar plans referred to in the preceding paragraph, that of the Peoria \& Eastern Railway Company affected only about $\$ 8,000,000$ of securities. The same singular factors of a single mortgage and a source of cash were necessary to enable the carrying out of the Boston and Maine plan, however.

"Those of the Lehigh Valley and the B. \& O. "s Senate Hearings, 119.

"See Montana, W. \& S. R. R. Financial Readjustment; and Pcoria \& E. Ry. Financial Readjustment, both supre note 42.

"T The Boston \& Maine plan formulated with the assistance of the R. F. C. provided for holders of the $\$ 103,833,000$ of bonds issued under the road's sole mortgage exchanging $50 \%$ of their holdings for new thirty-year $4 \%$ income bonds and taking either cash or new 20 -year $4 \%$ first morngage bonds for the $50 \%$ balance with the proviso that if more than about $25 \%$ of the bondholders elected to receive cash, the cash payment would be reduced below $50 \%$ and the difference paid in first mortgage bonds. Cash to meet the plan's requirements was lent the road by the R. F. C. which took 20-year $4 \%$ first mortgage bonds therefor. The plan, which reduces fixed interest by almost $\$ 3,000,000$ per 20 inum and total fixed and contingent interest by almost $\$ 1,000,000$, had been accepted by holders of over $93 \%$ of the outstanding bonds when it was declared effective. See MoODg's Rarrond SERvee (I940) 779. 
One other element which will affect the character of voluntary plans of which court approval is to be sought is the "fair plan" doctrine familiarly known as the doctrine of the Boyd case, ${ }^{48}$ or, lately, the Los Angeles Lumber Products Co. ${ }^{49}$ case. Since voluntary plans are not likely to involve any reduction of stock interests, the rule of absolute priorities enunciated by these cases will prohibit reductions in principal or interest of secured claims without adequate consideration therefor. This -means that there will be no straight reduction plans but that they will be either of the straight deferment or cash-reduction-deferment types. That even these plans may not meet the requirements of the strict priorities doctrine is demonstrated by comparing the mọst favorable, those involving a cash payment of part of the principal and a deferment of the balance, with the orthodox contract principle under which part payment in cash is not consideration for the extension of a matured claim. ${ }^{80}$

\section{The Future}

We come now to the question of what legislative provision, if any, should be made for future voluntary plans. With respect to straight deferment plans, the writer is satisfied that as a general proposition there is at the present time no need and no justification for a moratorium on railroad obligations which is precisely what a deferment plan provides. A moratorium is justifiable only if the payments extended can reasonably be expected to be made under normal future conditions. This raises the question of what the future reasonable expectations of the railroads are.

In 1939, and there has been little change since then, roads operating nearly one third of the country's mileage and having outstanding approximately one third of the railroad funded debt were in either receivership or reorganization proceedings. ${ }^{.1}$ Another third of the roads are marginal producers who continually have difficulty meeting their fixed charges often failing to do so. ${ }^{52}$ The remaining third of the roads are in reasonably strong financial condition.

It is apparent that only the middle group might find any use for a deferment procedure, for the roads in the first group admittedly require reorganization and those in the third consistently meet their fixed charges. The situation of the marginal carriers is such that deferment is not likely to solve their present problems. A sampling of 21 of these roads reveals that they have tailed to meet their fixed charges in almost half the years from 1930 to 1937 , and of the least successful ten an average of less than four in each year have done so. Even in 1937 , the best railroad year since 1930, only three of these ten earned fixed charges and the most successful of the three did so by only $1.11 \%{ }^{53}$ Discouraging as the recent history of the marginal

* Northern Dac. R. R. จ. Boyd, 228 U. S. $4^{82}$ (1973).

"Case v. Los Angeles Lumber Products Co., 308 U. S. 106 (1939). As to the effect of the Los Angeles case on voluntary plans, see Dodd, The Los Angeles Lumber Products Company Case and Iss Implications (1940) 53 HARv. L. Rev. 713, 747 et seq.

so See I Williston, Contracts (rev. ed. 1936) \$120.

"S2 See Clay, What Shall We Do about the Ralroade? (1939) 4.

I Ibid. No. 4).

${ }^{62}$ See The Rehabilitation of Ralload Credit, Ry. Busswess Ass'N., SExizs 1939, No. 7, p. 27 (Table 
carriers is, the futility of deferring charges which they are now unable to meet bcomes more apparent upon an examination of their future. The earnings prospects of these carriers, in the absence of unique considerations applicable to individual roads, are no better than those of the railroads generally.

One of the surest, quickest ways to appraise the future of any industry as old as the railroads is to examine the trend of its revenues and earnings. The revenue trends of the railroad industry since $18 g 9$ are very revealing. From that year through r920, railroad tonnage and revenues advanced at a faster rate than business activity generally. 54 Although gross railroad tonnage continued to increase from 1920 to I929, it did so at a slower rate than that of general business expansion. The railroads were not holding their own though the general prosperity of the period served to obscure this trend."5 This slowing down is further demonstrated by the fact that from I921 through 1936, while some new mileage was constructed, the entire railroad system sustained a nẹt loss through abandonment of 10,279 miles. ${ }^{56}$

The comparative decline of the railroads has continued at a surprisingly steady rate. In 1937, the best railroad year since 1930, though the Federal Reserve Board Index of Industrial Production averaged 110 as against III for 1928 , railroad freight tonnage was $21.1 \%$ and freight revenue $282 \%$ below 1928 . Total revenues were $31.9 \%$ below $x 928$, indicating that passenger revenues had fallen off even more sharply. ${ }^{67}$ -

While the present improvement in general business conditions will make for increased railroad revenues, there is nothing to indicate that the railroads will reverse their twenty year declining trend. The use of trucks, buses, motor cars, airplanes, pipe lines, inland water carriers, high transmission lines and other forms of transportation continues to increase in part at the expense of the railroads. In the absence of singular circumstances affecting individual carriers - or particular geographical areas, it seems safe to predict that the relative position of the railroads will decline until a new level of stability is reached.

Marginal producers in a declining industry are not likely to. benefit by a moratorium. There are, with rare exception, no roads now unable to meet principal or interest maturities, the business of which. is likely to improve in the next decade sufficiently to enable them to consistently meet their present charges, in other words, no roads of the type for whose benefit Chapter $X V$ was ostensibly conceived.88 The

"In 1899, railroads as 2 whole originated 13.4 tons of freight and had revenues of $\$ 24.40$ per unit of industrial production. By 1920 these figures had increased to 16.5 tons and $\$ 53.45$ respectively, the greater rise in revenues being due to sharply higher freight rates. See Moody's Mavual of Investrents, RAILROAd Secusities (1939) 23.

sE For a more detailed discussion of these trends, see Moody's, op. cit. supre note 54, 2 t 23 et seg.

" Palmer, Investisent Salvage in Ralloond Reorganizations (1938) 89.

"Moody's, op. cit. supra note 54, 24 24. There are also listed on p. 24 nine of the principal reasons for the relative decline of the railroads.

"See the testimony of one of the authors of Chapter XV, Col. Henry. W. Anderson, special counsel for the B. \& O., in which he divides railroads into three financial catcgories, those having no financial troubles, those having financial diffculties but not r=quiring reorganization, and those requiring drastic reorganizacion, and commends Chapter XV to the middle group. Hearings of the Special Subcommittee on Bonk- 
railroads which now find themselves in distress need substantial reductions in fixed charges and a present moratorium merely defers the inevitable reorganization while piling up large accumulations of deferred interest in the interim. As one railroad observer has well said, "The railroads not only need more business-they need relief from archaic capital structures." 59

In this respect a comparison between the capitalization of British and American sailroads is quite interesting. Whereas the fixed obligations of all American railroads average $62 \%$ of their total capitalization and equity securities represent only $38 \%$ thereof, the four largest British roads show $71.3 \%$ of their capitalization in share capital with only $28.7 \%$ in loan capital..$^{60}$ This means that the British roads have 2 substantial cushion of safety and may explain why financial failure is practically unknown among them, while reorganization is a familiar event in many American roads. Such a safety margin is particularly desirable in a declining industry.

It is frequently stated that on the basis of cost or reproduction value of their property American railroads are not overcapitalized. While this is true, it is equally true that on the basis of their earning capacity they are overcapitalized, and with capital structures top-heavy with fixed obligations the earning capacity is far more important than cost or reproduction value. 01

Not orly is reduction of fixed charges for roads now in distress necessary to prevent recurrence of the present difficulties, but such a reduction would redound greatly to the benefit of the roads and to their security holders in a variety of ways. It is an interesting fact that while the operating revenues per mile of line of the financially strong and the marginal roads for 1937 were approximately the same, the fixed charges per dollar of revenue of the later were from 14 to $31 \%$ greater. At the same time, and this is quite important, the net available for fixed charges per dollar of revenue of the strong roads was almost $25 \%$ greater than that of the marginal operators. While the revenue per mile of line of the two classes of carriers was practically the same, the financially strong roads not only had substantially smaller fixed charges, but also had lower operating costs per dollar of revenue and therefore more available to meet their lower charges. ${ }^{62}$

This indicates that, as might be anticipated, the financially straitened roads operate less efficiently. Much of this operating inefficiency results from insufficient or in. adequate equipment, old light rail, winding road-beds and manifold grade crossings, all of which make for extraordinary maintenance and slower service. Still another source of waste is antiquated shop facilities. Further, the necessity for meeting the over-burdening fixed charges tends to induce deferment of desirable maintenance resulting in depreciation of the property and greater expense in the future.

ruptcy and Reorganization of the House Comminte on the Judiciary, on H. R. 3704 and H. R. 5107 , 76th Cong, 1st Sess. (1939) 22. "Cun, op. cis. supre note 51, at 5.

- Bussing, op. cit. supra note 2, at 7 ef seq. Several counterbalancing factors which make a comparisan of British and American railroads reasonably trustworthy are discussed at p. 7 .

'See Clay, op. cit. supra note 51, at $42 \mathrm{et}$ seq.; The Rehabilitation of Railroad Credit, supra note 53.

"s See id. at 6 (Table 1). 
These considerations coupled with the declining character of the industry make it apparent that roads now unable to meet their maturities will not find deferment of these charges with no permanent reductions therein of any real benefit.

While there appears to be no rcal place for moratoria plans, there is a most useful field for plans providing permanent reductions of principal and interest. While thus far no reductions involving more than a single issue have been effected voluntarily, it is conceivable that large-scale plans may be carried through without the extended proceedings now characteristic of Section 77 . The possibility that even a relatively few single or multiple issue reductions may be effected voluntarily justifies some form of legislation providing for binding non-assenters to such a plan.

Any such new legislation, however, should be available only for plans providing substantial reductions of principal and interest maturities. In addition, the procedure should provide essential safeguards not present in Chapter XV. Effective examination of the plan by both the I. C. C. and the court should be assured through the elimination of the pressure elements of Chapter XV. An express prohibition, similar to that in Chapter X, on the solicitation of assents to the plan before approval by both the Commission and the court should be included. ${ }^{35}$ This is far more important with respect to voluntary management plans than for the typical Chapter X plan which is formulated only after careful negotiation among representatives of all classes of security holders.

Finally, the I. C. C. should be specifically authorized to amend the plan, if necessary, and be required to find that it is "fair and equitable"

While other desirable provisions will be apparent from the observations heretofore made, these are essential: a limitation to plans providing for substantial reductions, provision for pressure-free consideration of them by both the Commission and the court, authorization to the Commission to amend the plans, and finally, a requirement that the I. C. C. as well as the court approve their fairness. While the number of plans which can be effected under such limitations and provisions is probably small, no legislation for voluntary plans should be enacted without these basic protective measures, for an unsound plan rather than assisting the particular carries may result in the accumulation of an insurmountable debt burden which will make the ultimate reductions the more drastic and painful and result in an aggregate loss much greater than if the carrier were financially stabilized at the present time. ${ }^{.64}$

\footnotetext{
"S Chapter X, 5r76, 11 U. S. C. A. 3576 (1939).

" This was pointed out by Commissioner Eastman as follows: "... such 2 plan only defers the evil day and makes it worse when it finally arrives" Hearings, supra note 58, at 83 .
} 